\title{
Propolis Inhibits Neurite Outgrowth in Differentiating SH-SY5Y Human Neuroblastoma Cells
}

\author{
Han Bit Kim and Byung Sun Yoo \\ Dept. of Life Science, Kyonggi University, Suwon, Korea
}

(Received June 7, 2016; Revised June 15, 2016; Accepted June 16, 2016)

\begin{abstract}
Propolis is a multicomponent, active, complex resinous substance collected by honeybees from a variety of plant sources. We have studied the effect of propolis on neurite outgrowth of SH-SY5Y human neuroblastoma cells induced to differentiate by all-trans-retinoic acid (RA). Propolis, at a concentration of $3 \mu \mathrm{g} /$ $\mathrm{mL}$, had no significant effect on the viability of differentiating SH-SY5Y cells. However, the neurite outgrowth of the differentiating SH-SY5Y cells treated with propolis $(0.3 \sim 3 \mu \mathrm{g} / \mathrm{mL})$ for $48 \mathrm{hr}$ was significantly inhibited in a dose-dependent manner. Treatment of RA-stimulated differentiating SH-SY5Y cells with 0.3 to $3 \mu \mathrm{g} / \mathrm{mL}$ propolis resulted in decreased level of transglutaminase and 43-kDa growth-associated protein (GAP-43) in a dose-dependent manner. The results indicate that propolis is able to inhibit neurite outgrowth of differentiating SH-SY5Y cells.
\end{abstract}

Key words: Propolis, SH-SY5Y neuroblastoma cell, Neurite outgrowth, TGase, GAP-43

\section{INTRODUCTION}

Propolis is made from a sticky substance that honeybees produce by mixing their own waxes with resinous sap obtained from certain trees and other flowering plants. Propolis has been popularly used in folk medicine. The putative therapeutic properties of propolis could be related to its anti-bacterial (1), anti-inflammatory (2), anti-oxidative $(3,4)$, and tumoricidal activities $(5,6)$. Although propolis contains more than 300 different chemical compounds, phenolic acids and esters, polyphenols such as flavonoids and phenolic acids/ ester are relatively popular constituents (7). It has been well demonstrated that propolis has a distinct pronounced cytotoxic and anticarcinogenic effect in tumor cell models (8-10).

Established cell lines derived from nervous system tissue have proven to be powerful tools for elucidating cellular and molecular mechanisms of nervous system development and function. They also have been used to understand the action mechanism of neurotoxic chemicals. As neurons showing characteristic morphology with many cell pro-

Correspondence to: Byung Sun Yoo, Dept. of Life Science, Kyonggi University, San94-6, Yeongtong-gu, Suwon, Gyeonggi-do 16227, Korea

E-mail: yoobs@kgu.ac.kr

This is an Open-Access article distributed under the terms of the Creative Commons Attribution Non-Commercial License (http:// creativecommons.org/licenses/by-nc/3.0) which permits unrestricted non-commercial use, distribution, and reproduction in any medium, provided the original work is properly cited. cesses have the ability of extending neurite, neurite outgrowth in cultured neurons is considered one indication of neuroregenerative potential $(11,12)$. The human SH-SY5Y neuroblastoma cell line has the capability of undergoing neuronal maturation. It can be differentiated into neuronlike cells with neurites in response to all-trans-retinoic acid (RA) stimulation (13). Therefore, it has been used as in vitro cell model for studying the mechanisms of neuronal differentiation and neurotoxicity $(14,15)$. Neuronal differentiation of SH-SY5Y cells in response to RA is coupled with increased expression and activation of transglutaminase (TGase) (16). It was demonstrated that TGase is required for the promotion of neurite outgrowth (17). Growth-associated protein 43 (GAP-43), a nervous tissue-specific cytoplasmic protein, has been termed a 'growth' or 'plasticity' protein because it is expressed at high levels in neuronal growth cones during development and axonal regeneration (18).

In the present study, we investigated the effect of propolis on RA-induced differentiation of SH-SY5Y human neuroblastoma cell line. We found that propolis inhibited the neurite outgrowth and the expression of TGase protein of differentiating SH-SY5Y neuroblastoma cells.

\section{MATERIALS AND METHODS}

Propolis. Crude propolis was collected from the region of Yongin (Gyeonggi, Korea), and kept desiccated in a refrigerator $\left(-20^{\circ} \mathrm{C}\right)$ before being processed. Ethanol propolis extract (EEP) was prepared by the following procedure. 
Briefly, frozen propolis was powdered in a blender, placed in $95 \%$ ethanol solution and incubated at room temperature for 3 months. The ethanol extract was filtered through Whatman No. 2 paper. The filtered ethanol extract $(1 \mathrm{~mL})$ was evaporated to dryness, yielding $200 \mathrm{mg}$. Propolis was dissolved in $95 \%$ ethanol solution.

Cell culture. SH-SY5Y human neuroblastoma cells were purchased from Korean Cell Line Bank (Seoul, Korea). Cells were maintained in complete culture medium consisting of Ham's F12 and Eagle's minimum essential medium (Invitrogen Co., Carlsbad, CA, USA) supplemented with $10 \%$ heat-inactivated fetal bovine serum (Hyclone, Logan, Utah, USA) plus 100 units $/ \mathrm{mL}$ penicillin, $100 \mu \mathrm{g} / \mathrm{mL}$ streptomycin, and nonessential amino acids in a humidified incubator with $5 \% \mathrm{CO}_{2}$ and $95 \%$ air at $37^{\circ} \mathrm{C}$. The medium was refreshed every 2 days.

Propolis treatment. For differentiation studies, the cells were plated in 24-well plates at a density of $1 \times 10^{5}$ cells $/ \mathrm{mL}$. After incubation for 2 days, $10 \mu \mathrm{M}$ all-trans-RA was added to the medium for 2 days. Cells treated with RA showed significant neurite outgrowth. In the case of chemical treatment of cells undergoing differentiation, the SH-SY5Y cells were plated in the same way. After incubation for 2 days, $10 \mu \mathrm{M}$ RA and various concentrations of propolis were treated simultaneously.

Cell viability. The methylthiazoltetrazolium (MTT) assay was performed to measure cytotoxicity of propolis on differentiating SH-SY5Y cells. Cells were plated in 24-well plates at a density of $1 \times 10^{5}$ cells $/ \mathrm{mL}$. After incubation for $24 \mathrm{hr}$, the medium was refreshed, and propolis $(0.3$ and $3 \mu \mathrm{g} / \mathrm{mL}$ ) was administered for 2 days in the presence or absence of $10 \mu \mathrm{M}$ RA. Following exposure to propolis, the cells were incubated for $4 \mathrm{hr}$ with $0.5 \mathrm{mg} / \mathrm{mL}$ MTT at $37^{\circ} \mathrm{C}$. The reaction was stopped by removing the medium and adding acid isopropanol. The absorbance was measured at $540 \mathrm{~nm}$ of wavelength using a microplate reader (Bio-Rad Laoratories, Hercules, CA, USA).

Cell morphological analysis. SH-SY5Y cells were plated in 24-well plates at a density of $1 \times 10^{5}$ cells $/ \mathrm{mL}$. After incubation for $24 \mathrm{hr}$, the medium was refreshed, and $10 \mu \mathrm{M} \mathrm{RA}$ and various concentrations of propolis were added simultaneously. After incubation for 2 days, the cells were fixed in $4 \%$ paraformaldehyde in phosphate-buffered saline (PBS) for $3 \mathrm{~min}$, washed with PBS, stained with Coomassie Brilliant Blue, and washed with PBS. The morphological changes in the cells were observed under a phase-contrast microscope. Those cells whose cell body diameters longer than twice of the diameter of cell body were considered as neurite-bearing cells (19). The percentage of the cells with neurites in a particular culture was determined by counting at least 200 cells in each sample.
Western blot analysis. For Western blot analysis, SHSY5Y cells were plated in $100-\mathrm{mm}$ plates at a density of $1 \times 10^{5}$ cells $/ \mathrm{mL}(10 \mathrm{~mL})$. After incubation for $24 \mathrm{hr}$, the medium was refreshed and incubated in the presence and absence of RA and propolis. After incubation for indicated times, the cells were washed with ice-cold PBS and lysed with lysis buffer (50 mM 4-(2-Hydroxyethyl)piperazine-1ethanesulfonic acid $\mathrm{pH} 7.5,150 \mathrm{mM} \mathrm{NaCl}, 10 \%$ glycerol, $1 \%$ Triton X-100, $1.5 \mathrm{mM} \mathrm{MgCl}_{2}, 5 \mathrm{mM}$ EDTA) containing protease inhibitor cocktail (Sigma-Aldrich Korea Ltd., Yongin, Korea) at $4^{\circ} \mathrm{C}$ for $30 \mathrm{~min}$. Total proteins were obtained after centrifugation at $10,000 \times \mathrm{g}$ for $30 \mathrm{~min}$ at $4^{\circ} \mathrm{C}$. The protein concentrations were determined by Bradford assay (Pierce, Rockford, Illinois). All proteins were separated by $10 \%$ sodium dodecyl sulfate-polyacrylamide gel and electrophoretically transferred to polyvinyl difluoride nitrocellulose membrane (Millipore Co., Bedford, MA, USA). After blocking at room temperature for $90 \mathrm{~min}$ in Tris-buffered saline (TBS)Tween containing 5\% skim milk, the membranes were incubated with primary antibodies of anti-TGase (Santa Crus, CA, USA) and anti-GAP-43 (Santa Crus), followed by incubation with horseradish peroxidase-conjugated secondary antibody (Zymed, San Francisco, CA, USA). After washing 5 times with TBS-Tween, the bands were detected with a standard ECL detection system (LabFrontier Co., Seoul, Korea).

Statistical analysis. Results were expressed as mean values \pm standard error (mean \pm S.E.). Statistical analysis was performed by Student's t-test. A level of $p<0.05$ was considered to be significant.

\section{RESULT}

Propolis inhibits neurite outgrowth of differentiating SH-SY5Y neuroblastoma cells. The composition of propolis depends on the vegetation of the collection area (20). The estimation of total flavonoid contents in the ethanol extracts of our propolis was done by colorimetric method. We used quercetin as a standard compound. The total flavonoid content of our propolis sample was $10.31 \pm 0.84 \mathrm{~g}$ per $100 \mathrm{~g}$ ethanol extract.

To investigate the effect of propolis on differentiation of SH-SY5Y human neuroblastoma cells, we first determined the suitable subacute propolis concentrations. Cells were treated with propolis $(0.3$ and $3 \mu \mathrm{g} / \mathrm{mL})$ for 2 days in the presence of $10 \mu \mathrm{M}$ RA. Following exposure to propolis, viability of SH-SY5Y cells was determined by the MTT assay. The percentage of viable cells was calculated by defining the viability of cells without RA and propolis treatment as $100 \%$. Data are expressed as the mean \pm standard error obtained from 4 independent experiments. As shown in Fig. 1 , up to $3 \mu \mathrm{g} / \mathrm{mL}$ of propolis had no significant effect on the viability of differentiating SH-SY5Y neuroblastoma cells.

The effects of propolis on the differentiation of SH-SY5Y 


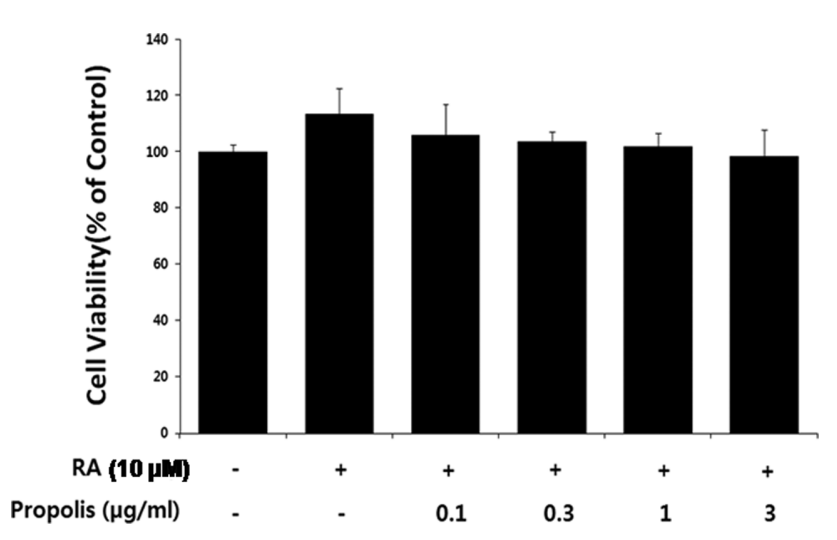

Fig. 1. Effect of propolis on the cell viability of differentiating SH-SY5Y cells. The cells were treated with propolis for $48 \mathrm{hr}$ in the presence of RA $(10 \mu \mathrm{M})$. Then, the viability of SH-SY5Y cells was determined by MTT assay. The percentage of viable cells was calculated by defining the viability of cells without RA and propolis treatment as $100 \%$. Data are expressed as the mean \pm standard error obtained from four independent experiments.

cells induced by RA was initially assessed by examining the effect on neurite outgrowth. Propolis was used at various concentrations up to $3 \mu \mathrm{g} / \mathrm{mL}$, which had no significant effect on the viability of differentiating SH-SY5Y cells. Although propolis had no significant effect on the cell viability at concentrations $(<3 \mu \mathrm{g} / \mathrm{mL})$, the neurite outgrowth of differentiating SH-SY5Y cells at concentrations of 0.3 to $3 \mu \mathrm{g} / \mathrm{mL}$ propolis was significantly inhibited in a dose-dependent manner (Fig. 2).

Propolis decreased the expression levels of TGase and GAP-43 proteins of differentiating SH-SY5Y neuroblastoma cells. The molecular basis of the inhibitory effects of propolis on neurite outgrowth of SH-SY5Y cells was
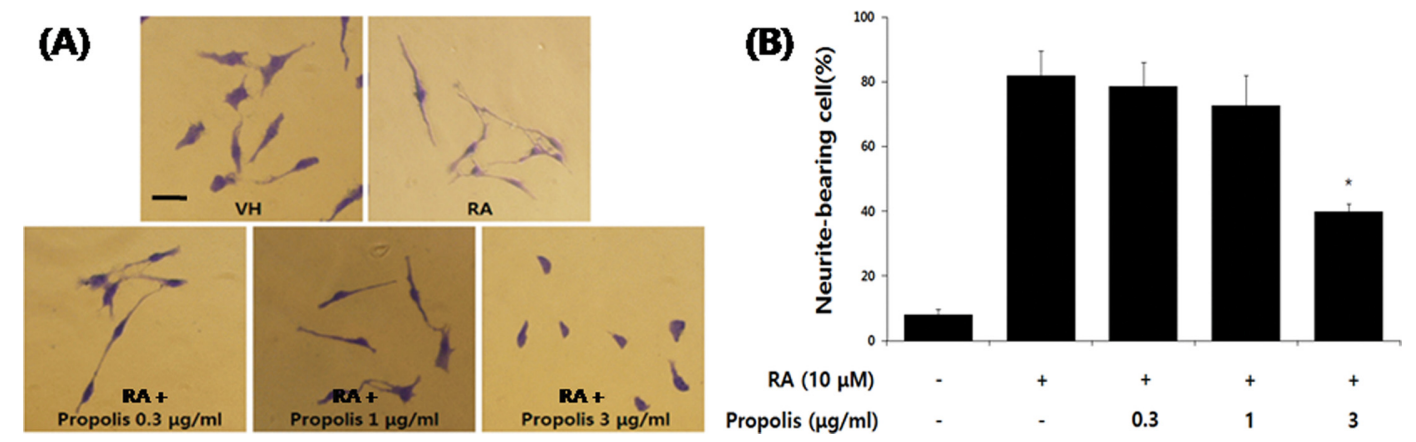

Fig. 2. Effects of propolis on neurite outgrowth in differentiating SH-SY5Y neuroblastoma cells. (A) The cells were induced to differentiate for $48 \mathrm{hr}$ with RA $(10 \mu \mathrm{M})$ in the presence or absence of propolis $(0.3 \sim 3 \mu \mathrm{g} / \mathrm{mL})$. Cells were fixed in $4 \%$ paraformaldehyde and stained with Coomassie Brilliant Blue (CBB). Shown are images of typical fields of cells viewed by inverted light microscope. (B) Neurite outgrowth was quantified by counting the number of cells exhibiting neurites that were two times longer than the cell body diameter in length. The proportion of cells with neurites was expressed as a percentage of the total number of cells. Approximately 300 cells were counted in each sample. The data are expressed as the mean \pm standard error of four independent experiments. ${ }^{*} p<0.05$ when compared to RA-treated cells. Scale bar $=100 \mu \mathrm{m}$. 


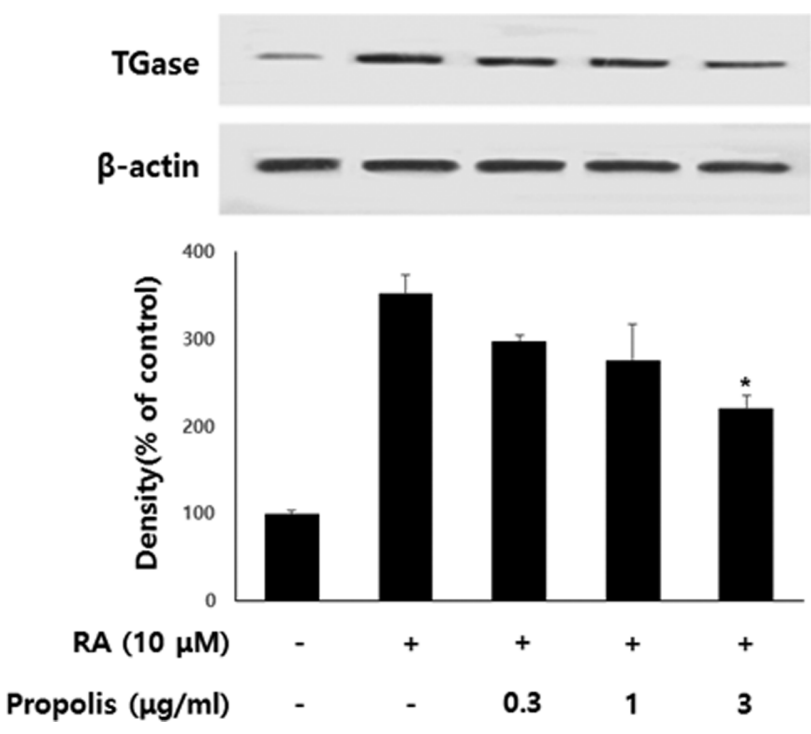

Fig. 3. Effect of propolis on the expression of TGase in differentiating SH-SY5Y cells. The cells were treated with various concentrations of RA $(10 \mu \mathrm{M})$ and propolis for $48 \mathrm{hr}$. The Western blot data represents one of three experiments. Densitometric analysis was performed to determine the intensity of TGase bands. Values are normalized to $\beta$-actin band and expressed as the percentage of cells treated with retinoic acid (RA) only. Data are mean \pm standard error of three independent experiments. ${ }^{*} p<0.05$ when compared to RA-treated cells.

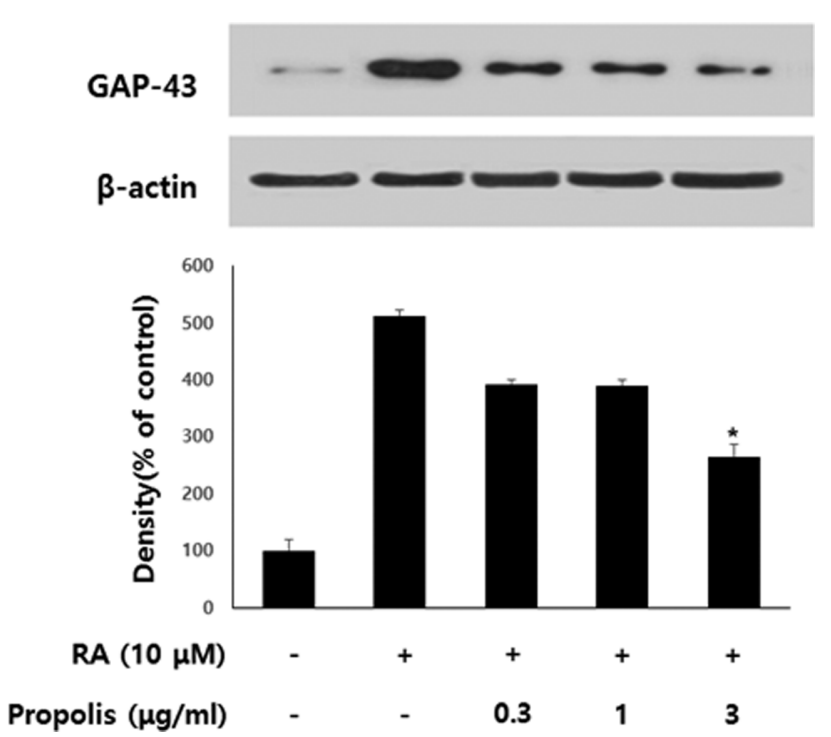

Fig. 4. Effect of propolis on the expression of GAP-43 in differentiating SH-SY5Y cells. The cells were treated with various concentrations of propolis in the presence of $10 \mu \mathrm{M}$ RA for $48 \mathrm{hr}$. The Western blot data represents one of three experiments. Densitometric analysis was performed to determine the intensity of GAP-43 bands. Values are normalized to $\beta$-actin band and expressed as the percentage of cells treated with retinoic acid (RA) only. Data are mean standard error of three independent experiments. ${ }^{*} p<0.05$ when compared to RA-treated cells. rosystem remain undefined. It has been suggested that in vitro methods are useful for preliminary investigation of the possible potential of a natural product (30). If such in vitro assays yield positive results, further investigation is necessary to produce data with clinical relevance. Moreover, in vitro and in vivo assays do not always include chemically characterized extracts, and one should take into account that pharmacological variability of preparations is expected (30).

A number of human neuroblastoma cell lines including IMR-32, SH-SY5Y, and SK-N-SH cells have been used to evaluate the effects of toxicants on neurite outgrowth (31). Any changes in neurite outgrowth in differentiating neurons can be used for the elucidation of neuroregenerative potential (32). SH-SY5Y human neuroblastoma cells can be differentiated into neuron-like cells with neurites in response to all-trans-RA stimulation (13). It has been used as an in vitro cell model for studying potential mechanisms of neurotoxicity.

In our experiment, we investigated the effect of propolis on nerve system using SH-SY-5Y human neuroblastoma cell line. Human SH-SY5Y neuroblastoma cells could be induced to differentiate by $10 \mu \mathrm{M}$ all-trans retinoic acid (RA) treatment. We demonstrated that propolis inhibited neurite outgrowth of differentiating SH-SY5Y neuroblastoma cells. And propolis decreased the expression of TGase and GAP43 proteins, common markers of differentiating neuroblastoma cells. These results suggest the potential effect of propolis on the differentiation of neuron.

\section{ACKNOWLEDGEMENTS}

We would like to thank Dr. Sang Bok Kim (AECL, Canada) for english correction. Funding for this paper was provided by Kyonggi University (2003).

\section{CONFLICT OF INTEREST}

Authors declare that there are no conflicts of interest.

\section{REFERENCES}

1. Drago, B., Mombelli, B., De Vecchi, E., Fassina, M.C., Tocalli, L. and Gismondo, M.R. (2000) In vitro antimicrobial activity of propolis dry extract. J. Chemother., 12, 390-395.

2. Mizoeva, O.K. and Calder, P.C. (1996) The effect of propolis and its components on eicosanoid production during the inflammatory response. Prostaglandins Leukot. Essent. Fatty Acids, 55, 441-449.

3. Krol, W., Czuba, Z., Scheller, S., Gabrys, J., Grabiec, S. and Shani, J. (1990) Anti-oxidant property of ethanolic extract of propolis (EEP) as evaluated by inhibiting the chemiluminescence oxidation of luminal. Biochem. Int., 21, 593-597.

4. Scheller, S., Wilczok, T., Imielski, S., Krol, W., Gabrys, J. and Shani, J. (1990) Free radical scavenging by ethanol extract of 
propolis. Int. J. Radiat. Biol., 57, 461-465.

5. Chen, S.N., Weng, M.S., Wu, C.L. and Lin, J.K. (2004) Comparison of radical scavenging activity, cytotoxic effects and apoptosis induction in human melanoma cells by Taiwanese propolis from different sources. Evid. Based Complement. Alternat. Med., 1, 175-185.

6. Matsuno, T. (1993) Isolation and characterization of the tumoricidal substance from Brazilian propolis. Honeybee Sci., 13, 49-54.

7. Castaldo, S. and Capasso, F. (2002) Propolis, an old remedy used in modern medicine. Fitoterapia, 73, S1-S6.

8. Scheller, S., Krol, W., Swiacik, J., Owezarek, S., Gabrys, J. and Shani, J. (1989) Antitumoral property of ethanolic extract of propolis in mice-bearing Ehrlich carcinoma, as compared to bleomycin. Z. Naturforsch., C, J. Biosci., 44, 1063-1065.

9. Chiao, C., Carothers, A.M., Grunberger, D., Solomon, G., Preston, A.G. and Barrett, C.J. (1995) Apoptosis and altered redox state induced by caffeic acid phenethyl ester (CAPE) in transformed rat fibroblast cells. Cancer Res., 55, 3576-3583.

10. Rao, C.V., Desai, D., Rivenson, A., Simi, B., Amin, S. and Reddy, B.S. (1995) Chemoprevention of colon carcinogenesis by phenylethyl-3-methylcaffeate. Cancer Res., 55, 2310-2315.

11. Fournier, A.E., Takizawa, B.T. and Strittmatte, S.M. (2003) Rho kinase inhibition enhances axonal regeneration in the injured CNS. J. Neurosci., 23, 1416-1423.

12. Lehmann, M., Fournier, A., Selles-Navarro, I., Dergham, P., Sebok, A., Leclerc, N., Tigyi, G. and McKerracher, L. (1999) Inactivation of Rho signaling pathway promotes CNS axon regeneration. J. Neurosci., 19, 7537-7547.

13. Itano, Y. and Nomura, Y. (1995) 1-Methyl-4-phenylpyridinium ion (MPP+) causes DNA fragmentation and increases Bcl-2 expression in human neuroblastoma, SH-SY5Y cells, through different mechanisms. Brain Res., 704, 240-245.

14. Tosetti, P., Taglietti, V. and Toselli, M. (1998) Functional changes in potassium conductances of the human neuroblastoma cell line SH-SY5Y during in vitro differentiation. $J$. Neurophysiol., 79, 648-658.

15. Uberti, D., Piccioni, L., Colzi, A., Bravi, D., Canonico, P.L. and Memo, M. (2002) Pergolide protects SH-SY5Y cells against neurodegeneration induced by $\mathrm{H}_{2} \mathrm{O}_{2}$. Eur. J. Pharmacol., 434, 17-20.

16. Singh, U.S., Pan, J., Kao, Y.L., Joshi, S., Young, K.L. and Baker, K.M. (2003) Tissue transglutaminase mediates activation of RhoA and MAP kinase pathways during retinoic acidinduced neuronal differentiation of SH-SY5Y cells. J. Biol. Chem., 278, 391-399.

17. Tucholski, J., Lesort, M. and Johnson, G.V. (2001) Tissue transglutaminase is essential for neurite outgrowth in human neuroblastoma SHSY5Y cells. Neuroscience, 102, 481-491.

18. Kosik, K.S., Orecchio, L.D., Bruns, G.A., Benowitz, L.I., MacDonald, G.P., Cox, D.R. and Neve, R.L. (1988) Human GAP-43: its deduced amino acid sequence and chromosomal localization in mouse and human. Neuron, 1, 127-132.
19. Keilbaugh, S.A., Prusoff, W.H. and Simpson, M.V. (1991) The PC12 cell as a model for studies of the mechanism of induction of peripheral neuropathy by anti-HIV-1 dideoxynucleoside analogs. Biochem. Pharmacol., 42, R5-R8.

20. Bankova, V.S., De Castro, S.L. and Marucci, M.C. (2000) Propolis: recent advances in chemistry and plant origin. Apidologie, 31, 3-15.

21. Tucholski, J., Lesort, M. and Johnson, G.V. (2001) Tissue transglutaminase is essential for neurite outgrowth in human neuroblastoma SH-SY5Y cells. Neuroscience, 102, 481-491.

22. Zhang, J., Lesort, M., Guttmann, R.P. and Johnson, G.V. (1998) Modulation of the in situ activity of tissue transglutaminase by calcium and GTP. J. Biol. Chem., 273, 2288-2295.

23. Sidell, N. (1982) Retinoic acid-induced growth inhibition and morphologic differentiation of human neuroblastoma cells in vitro. J. Natl. Cancer Inst., 68, 589-596.

24. Påhlman, S., Ruusala, A.I., Abrahamsson, L., Mattsson, M.E. and Esscher, T. (1984) Retinoic acid-induced differentiation of cultured human neuroblastoma cells: a comparison with phorbolester-induced differentiation. Cell Differ., 14, 135-144.

25. Sforcin, J.M., Kaneno, R. and Funari, S.R.C. (2002) Absence of seasonal effect on the immunomodulatory action of Brazilian propolis on natural killer activity. J. Venom. Anim. Toxins, 8, 19-29.

26. Chen, Y.J., Huang, A.C., Chang, H.H., Liao, H.F., Jiang, C.M., Lai, L.Y., Chan, J.T., Chen, Y.Y. and Chiang, J. (2009) Caffeic acid phenethyl ester, an antioxidant from propolis, protects peripheral blood mononuclear cells of competitive cyclists against hyperthermal stress. J. Food Sci., 74, H162H167.

27. Gekker, G., Hu, S., Spivak, M., Lokensgard, J.R. and Peterson, P.K. (2005) Anti-HIV-1 activity of propolis in CD4(+) lymphocyte and microglial cell cultures. J. Ethnopharmacol., 102, 158-163.

28. Sforcin, J.M., Fernandes, A. Jr., Lopes, C.A.M., Funari, S.R.C. and Bankova, V. (2001) Seasonal effect of Brazilian propolis on Candida albicans and Candida tropicalis. $J$. Venom. Anim. Toxins, 7, 139-144.

29. Freitas, S.F., Shinohara, L., Sforcin, J.M. and Guimaraes, S. (2006) In vitro effects of propolis on Giardia duodenalis trophozoites. Phytomedicine, 13, 170-175.

30. Heinrich, M., Modarai, M. and Kortenkamp, A. (2008) Herbal extracts used for upper respiratory tract infections: are there clinically relevant interactions with the cytochrome P450 enzyme system? Planta Med., 74, 657-660.

31. Edsjö, A., Holmquist, L. and Påhlman, S. (2007) Neuroblastoma as an experimental model for neuronal differentiation and hypoxia-induced tumor cell dedifferentiation. Semin. Cancer Biol., 17, 248-256.

32. Fournier, A.E., Takizawa, B.T. and Strittmatte, S.M. (2003) Rho kinase inhibition enhances axonal regeneration in the injured CNS. J. Neurosci., 23, 1416-1423. 